\title{
Interactions between Mule Deer and Cattle on Big Sagebrush Range in British Columbia
}

\author{
W. WILLMS, A. MCLEAN, R. TUCKER, AND R. RITCEY
}

\begin{abstract}
Interaction between deer and cattle took various forms. The potential for direct competition was greatest in spring. Both deer and cattle selected bluebunch wheatgrass and crested wheatgrass while Sandbergs bluegrass was most often used by deer. Evidence of indirect interaction was observed. Moderate or heavy fall grazing by cattle made the spring forage more attractive to deer by removing mature forage. Light grazing did not exert any appreciable effect on deer distribution.
\end{abstract}

The spring range of mule deer in south central British Columbia is relatively restricted, usually below $775 \mathrm{~m}$ elevation. This range is also used by cattle in both spring and fall, providing forage at a time crucial to a viable ranching operation. Common use of the range ensures that interaction between cattle and deer will occur. The type and extent of interaction was not known but was believed to be most critical in the food niche. A project was initiated in 1972 near Kamloops, British Columbia, to study interaction between the two species of ungulates for the range resource in terms of food, time and space. The study was supported by the Agriculture Canada Research Station, the British Columbia Fish and Wildlife Branch, and the British Columbia Ministry of Forests. Some of these have been reported previously (Tucker et al. 1976; Willms et al. 1976; McLean and Willms 1977; and Tucker et al. 1977).

\section{Site Description}

The study area was on the north side of Kamloops Lake, about 24 $\mathrm{km}$ west of Kamloops. This area lies within the big sagebrush (Artemisia tridentata), ponderosa pine (Pinus ponderosa), and Douglasfir (Pseudotsuga menziesii) zones. The land rises steeply from the lakc, at $335 \mathrm{~m}$, to a scrics of knolls and a relatively flat area before rising again within the open forest. Maximum elevation on this range is $760 \mathrm{~m}$. Snowfall is light and the direct southern exposure promotes early growth and a warm environment. The range had been heavily grazed from 1947 until 1965, when the grazing permit was cancelled to allow rehabilitation of overgrazed areas. One hundred hectares on the flat area were seeded to crested wheatgrass (Agropyron desertorum) in 1968.

Cattle normally use this range from early November to midDecember and again trom early April to the end of May. The same area may be occupied by deer from early December to the end of May, although the greatest use occurs in a 1-month period in March and April. Some deer may remain on this range into the summer.

\section{Methods}

Four habitats were recognized on the study area. The forested range

The authors are graduate student. Plant Science. University of Alberta: research ricntist and range technician. Research Station. Agriculture Canada; and wildlife bielogist. British Columbia Fish and Wildlife Branch, Camloops, B.C. Contribution no.

The atuhors are grateful for the dedicated assistance of $\mathrm{L}$. Stroesser and L. Haupt. celmicians, during the course of the project.

Manuscript received April 12. 1978. was considered as one and occupied $38 \%$ of the area. Three habitats on the open range, identified by topography, were a steep south-facing slope, a series of knolls, and a flat field, representing 15, 34 and $13 \%$ respectively of the total area.

Three hundred and seventy hectares were fenced to include both grassland and open forest. This area was divided into three fields, identified as east, west, and middle, each containing both open and forested range. A 1-ha deer and cattle exclosure was built in each field. These exclosures were located in the big sagebrush-bluebunch wheatgrass (Agropyron spicatum) community on a south-facing slope.

From 1972 to 1974 the grazing rotation was fixed. The east field was grazed only in fall, the middle field was grazed only in spring and the west field was grazed in both spring and fall. Since 1974, no field was grazed twice annually in consecutive years. Grazing pressure in each field varied from year to year but averaged 2.8 ha per animalunit-month (AUM). Changes in deer distribution were studied to assess grazing treatments in those fields.

\section{Vegetation Surveys}

Two paired $1-\mathrm{m}^{2}$ plots were established at 10 randomly selected locations in each habitat to estimate plant cover and forage utilization. The percent ground cover of every major species was estimated on each plot. An additional estimate of basal area for each perennial grass species was made in the spring. In both spring and fall, one pair of plots was harvested before and after cattle grazing. Forage production during the grazing period was estimated from sites protected by wire cages and the information extrapolated to the harvested plots by a relationship derived for weight $(y)$ and basal area $(x)$ of each major plant species. Consumption was calculated to be the difference between the first harvest plus subsequent growth and the second harvest.

\section{Cattle and Deer Distribution}

Cattle distribution was evaluated by direct observations made periodically during daylight hours in both spring and fall. Distribution of deer was studied using animal count, track counts, and pellet group counts. Animal counts were made from a road at irregular intervals during the day. Track counts were sampled on two 100-m long transects located parallel to the contour in both the tree and south slope habitats. In the winter of 1971-72, tracks in the snow or mud could bc surveyed until mid-March. After this period, 147 direct sightings were made. In the next winter the tracks could be surveyed until the end of February and then 93 direct sightings were made.

Pellet group counts were sampled prior to the reintroduction of cattle to study site and in the spring of each year thereafter. The first sample was made using a temporary belt transect extending perpendicular to the contour through each habitat. The belt was $2 \mathrm{~m}$ wide and partitioned into plots $20 \mathrm{~m}$ long. A permanent sampling system was later established. One transect was placed in each field to run parallel to the contour so that each habitat was sampled. Clusters of five circular plots, were spaced at intervals of $60 \mathrm{~m}$ on each transect. The plot diameters were $3.4 \mathrm{~m}$ and the cluster diameters were $32 \mathrm{~m}$. Pellet groups were counted every spring starting 1972.

Pellet group distribution provided an indication of relative use by deer in each habitat prior to grazing and in each field following 
grazing. The impact of cattle grazing on deer distribution was evaluated by comparing the relative change in pellet group counts from one year to the next.

\section{Cattle and Deer Diets}

The proportion of grass species in spring cattle diets was estimated by separating each at the time of the utilization surveys. No separations were made in the fall. The spring observations were for 2 years while the fall observations were for only 1 .

Two rumen-fistulated, identical twin beef cows were used to study forage selections by cattle. The animals were turned onto the range with other cattle during the normal grazing period in both spring and fall. Rumen samples were collected from each animal every 2 or 3 days during this period. The samples were washed on a $2.4 \mathrm{mesh} / \mathrm{cm}$ screen, air dried and hand separated to species with grass and grasslike species being pooled. The components were then oven-dried and weighed.

Rumen samples were collected from sacrificed free-ranging deer on the study area and from hunter- or road-killed animals nearby. Preparation for species separation and identification was the same as described above. Separation was modified with point sampling wherc the number of species in the sample was large. Grass and alfalfa were removed from the analysis when it was evident they originated from a domestic hay source.

Direct observations on tame deer werc used to supplement the rumen data. Three deer were observed from mid-February to the end of May on the knoll and flat field habitats. Forage selection was evaluated by the number of bites taken from each species. A bite was counted only when forage was prehended and ingested.

Winter forage selection by free-ranging deer was determined by following deer trails in the snow and counting the number of browsed stems on nearby plants. The contribution to the diet was calculated for each forage.

\section{Statistical Analysis}

Vegetative cover was expressed as percent of ground cover and forage contribution to the diet as percent of the total diet. Means and standard error of the means were calculated from the raw data. When analysis of variance were used to test the hypothesis, the data were transformed using the arcsine square root transformation (Goulden 1952). Analysis of variance was used to compare cattle and deer diets among seasons.

\section{Results and Discussion}

\section{Vegetation Survey}

The forage composition among the fields was similar. Crested wheatgrass dominated the flat-field habitat of the east (19\%) and middle (29\%) fields but also occurred on the tree habitat of the west field $(6 \%)$. Bluebunch wheatgrass was the dominant forage on the tree habitat in each field $(\simeq 23 \%)$ as well as a major representative on the south-slope habitat $(\simeq 10 \%)$. It dominated on the knoll habitat of the west field (19\%) but was minor on that habitat in other fields. Sandbergs bluegrass (Poa sandbergii) decreased from the east to west fields. Needleandthread (Stipa (comata) was also represented in major proportion in all habitats except the tree. Other grasses present, in decreasing order of importance, were cheatgrass (Bromus tectorum), sand dropseed
(Sporobolus cryptandrus), Junegrass (Koeleria cristata), threcawn (Aristida longiseta), and rough fescue (Festuca scabrella).

\section{Cattle Distribution}

Not all cattle were located in each observation. The probable distribution of those not accounted (Table 1) was primarily the tree habitat and secondarily the knoll habitat, based on the searchability of each.

Cattle distribution in fall appeared influenced primarily by forage availability and weather. In the first fall, cattle preferred the flatfield habitats, moved onto the flat-field and, occasionally, intercepted the knoll habitats, then back to the waterholes, where they normally rested. Resting also occurred anywhere along the feeding area when weather was favourable. During wind storms, however, the animals were more likely to be found in the shelter of the trees near the waterhole and less often in the depressions of the knoll habitat. Major changes in the distribution patterns of cattle did not occur till late in the grazing period when the combination of snowfall, low temperatures, and heavy utilization of the flat-field habitat caused cattle to increase their use of the tree habitat where bluebunch wheatgrass protruded above the snow.

The second fall (1973) was characterized by periods of snowfall and, melt. During warm periods most cattle use occurred on south-facing slopes where wind and snow melt first exposed the forage. During intermittent periods of snowfall and cold weather, cattle occupied the tree habitat. This resulted in very little forage utilization on the flat field but a proportionately higher degree of use on other habitats (Table 2).

Table 2. Consumption (percent estimated from clipping studies) of grass by cattle in each habitat during spring and fall.

\begin{tabular}{lcccc}
\hline & \multicolumn{4}{c}{ Habitat } \\
\cline { 2 - 5 } $\begin{array}{l}\text { Period and } \\
\text { observations }\end{array}$ & $\begin{array}{c}\text { South } \\
\text { slope }\end{array}$ & Knoll & Flat field & Tree \\
\hline $\begin{array}{l}\text { Fall 1973 } \\
\quad \text { Utilization } \\
\begin{array}{l}\text { Contribution to grass } \\
\text { intake }\end{array}\end{array}$ & 58 & 19 & 8 & 23 \\
$\begin{array}{l}\text { Spring 1973 and 1974 } \\
\text { Utilization } \\
\text { Contribution to grass } \\
\text { intake }\end{array}$ & 49 & 21 & 4 & 45 \\
\hline
\end{tabular}

1 Values are the anounts of forage removed from a habitat as a percentage of the forage removed from all habitats.

In spring the proportion of occupation and use was greatest on the flat-field habitat and least on the south-slope habitat (Tables $1 \& 2$ ). This may partly be explained as the reluctance of cattle to use stecp slopes (Mucggler 1965). On the other hand, the tree habitat was not steep but, compared to the flat-field habitat, was used much less. Presumably the water holes, located near the edge and outside of the tree habitat, did not encourage use of that range. Another factor not well understood is forage quality.

Table 1. Daytime cattle distribution (percent) for 2 years on spring and fall range.

\begin{tabular}{|c|c|c|c|c|c|c|c|c|c|}
\hline \multirow[b]{3}{*}{ Period } & \multicolumn{8}{|c|}{ Habitat } & \multirow{3}{*}{$\begin{array}{l}\text { Cattle not } \\
\text { counted }\end{array}$} \\
\hline & \multirow[b]{2}{*}{$\mathrm{n}$} & \multirow[b]{2}{*}{ South slope } & \multicolumn{2}{|c|}{ Knoll } & \multirow[b]{2}{*}{ Flat field } & \multirow{2}{*}{$\begin{array}{c}\text { Tree-open } \\
\text { ecotone }\end{array}$} & \multicolumn{2}{|c|}{ Tree } & \\
\hline & & & Range & Waterhole & & & Range & Waterhole & \\
\hline Fall 1972 & 757 & 1 & 11 & 0 & 19 & 8 & 5 & 29 & 27 \\
\hline Fall 1973 & 545 & 27 & 14 & 0 & 16 & 3 & 35 & 0 & 5 \\
\hline Spring 1973 & 1755 & 9 & 6 & 5 & 20 & 10 & 14 & 19 & 17 \\
\hline Spring 1974 & 256 & 0 & 17 & 0 & 41 & 20 & 2 & 0 & 20 \\
\hline
\end{tabular}


Marquiss et al. (1974) found crested wheatgrass to be more palatable than bluebunch wheatgrass. In this study crested wheatgrass was also utilized to a considerably greater degree than the latter species.

\section{Deer Distribution}

Deer distributed themselves on spring range according to a diurnal pattern modified by external factors. Prior to cattle grazing, the deer used the south-slope, knoll and tree habitats to a similar degree throughout the season and used the flat-field habitat very little. The average number of pellet groups counted per plot in each habitat, and the standard error of their means, were $6.1 \pm 0.8,5.7 \pm 0.5,8.4 \pm 0.6$, and $1.0 \pm 0.8$ from the first to the last habitat mentioned above. Periodic shifts in daytime distribution occurred in both winters that track and animal counts were made. In the first winter, use shifted from the tree habitat $(95 \%)$ in January to the warm open south-facing slope $(60 \%)$ at the end of February. Deer use continued on the south-slope and knoll habitats until early May (82\%) when use again shifted to the trees (90\%). In the second winter and spring most direct observations were made in the tree habitat $(68 \%)$ while use of the open habitats was limited (32\%) and occurred in April. It is possible the open habitat was used primarily for night feeding. Decline in use may have occurred that year as a result of low forage quantity and palatability on the open range. Low soil moisture and warm temperatures reduced forage production and accelerated phenological progression. This effect would be less severe in the tree habitat, where trapped snow and shade inhibited snow melt and evaporation.

\section{Cattle Diets}

Clipping studies in fall showed that the degree of grass use was greatest on the south-slope habitat and least on the flat-field habitat (Table 2). However, the tree habitat contributed most to total grass consumed. In spring, the degree of grass use was greatest on the flat-field habitat and least on the tree habitat. The flat-field habitat also contributed more to total grass consumed than did the other habitats (Table 2).

Grasses dominated the cattle diet in both seasons, as observed in rumen samples. Although the difference was small, the percentage of grass consumed was significantly $(P \leq 0.05)$ greater in spring (95.0) than in fall (91.9). Most of the remaining proportion consisted of tree species. The percentages of bluebunch wheatgrass, crested wheatgrass, and needleandthread in the diet were estimated from the clipping studies to be $+1,23$, and $25 \%$, respectively. The remaining $11 \%$ was made up of Sandbergs bluegrass, Junegrass, and sand dropseed. The degree of use of the three major species were: bluebunch wheatgrass $40 \%$, crested wheatgrass $79 \%$, and needleandthread $51 \%$.

A major contributor to the forb component of the diet in fall was bassia (Bassia hyssopifolia). Important shrubs were pasture sage (Artemisia frigida) and rose (Rosa spp.) in both seasons.
Ponderosa pine dominated the trec component of the diet in spring and shared dominance in fall with Douglasfir.

Cattle selected primarily bunchgrasses in both spring and fall. Utilization of Sandbergs bluegrass was not observed in either season and could not be estimated from the clipping trials because of its short leaf length. Skovlin et al. (1976) showed that Sandbergs bluegrass was used to some extent by cattle in Oregon, where it appears to grow taller.

\section{Deer Diets}

The presence of grasses, forbs, shrubs, and trees varied considerably in the rumen samples of deer from mid-September to the end of April (Table 3). Grasses dominated the spring diet, while forbs declined from $23 \%$ in fall to $4 \%$ in spring. Shrubs were used extensively in both fall and mid-winter but were minor components in early winter and spring. Trees dominated the diet in early winter.

The species composition of grass was estimated from observations of tame deer. From mid-February to the end of May, deer diets on the knoll habitat averaged $21 \%$ bluebunch wheatgrass and $55 \%$ Sandbergs bluegrass. The percentage of bluebunch wheatgrass remained relatively uniform throughout this period but the contribution of Sandbergs bluegrass ranged from $88 \%$ in March to $6 \%$ in May. Cheatgrass was selected only in May when it comprised $24 \%$ of the diet. Junegrass increased from $2 \%$ early in the period to $18 \%$ in May.

On the flat-field habitat Sandbergs bluegrass ranged from $94 \%$ of the grass component in the diet in late February to $3 \%$ in May. Crested wheatgrass was next in importance, increasing from $6 \%$ in February to $55 \%$ in May. Other species, in order of their importance in the grass component of the diet, were bluebunch wheatgrass, cheatgrass, Junegrass, and needleandthread. The species representing the forb component in the rumen samples varied throughout the period from mid-September to the end of April. In the first month the major species was tall wormwood (Artemisia campestris); but in November, asters (Aster spp.), thistle (Cirsium arvense), and twinflower (Linnciea borealis) were important. Cactus (Opuntia fragilis) was also a major forb in the diet during December and January.

The shrub component also varied in the rumen samples. From mid-September to the end of November, the evergreen shrubs, false box (Pachystima myrsinites) and Oregon grape (Berberis repens), dominated. In winter and spring, however, the shrub component consisted primarily of pasture sage, big sagebrush, and rabbitbrush (Chrysothamnus nauseosus), in approximately equal proportions.

The tree component consisted almost entirely of Douglasfir. In late winter ponderosa pine represented about one-quarter of the tree component.

\section{Deer Winter Diet}

The winter diet of deer in the study area consisted mostly of

Table 3. Composition (percent) of grasses, forbs, shrubs, and trees in the rumens of free ranging mule deer for five periods from September 15 to April 30 .

\begin{tabular}{|c|c|c|c|c|c|}
\hline \multirow[t]{2}{*}{ Plant type } & \multicolumn{5}{|c|}{$\begin{array}{c}\text { Period } \\
\text { (Number of samples) }\end{array}$} \\
\hline & $\begin{array}{l}\text { Sept. 15-Oct. } 31 \\
\text { (7) }\end{array}$ & $\begin{array}{c}\text { Nov. } 1-\text { Nov. } 30 \\
(20)\end{array}$ & $\begin{array}{l}\text { Dec. } 1-\text { Dec } 30 \\
\text { (17) }\end{array}$ & $\begin{array}{c}\text { Jan. I-Mar. } 15 \\
\text { (14) }\end{array}$ & $\begin{array}{c}\text { Mar. 16-Apr. 30 } \\
\text { (9) }\end{array}$ \\
\hline Grasses & $1.6 \pm 0.6 \mathrm{a}$ & $2.7 \pm 0.2 \mathrm{a}$ & $0.2 \pm 0.2 \mathrm{a}$ & $3.1 \pm 0.5 \mathrm{a}$ & $6+.0 \pm 1.9 \mathrm{~b}$ \\
\hline Forbs & $23.0 \pm 1.9 \mathrm{a}$ & $21.2 \pm 1.1 \mathrm{a}$ & $15.2 \pm 1.2 \mathrm{a}$ & $11.7 \pm 1.2 \mathrm{a}$ & $+.0 \pm 0.9 \mathrm{a}$ \\
\hline Shrubs & $53.9 \pm 2.0 \mathrm{~b}$ & $47.3 \pm 1.2 \mathrm{~b}$ & $17.1+1.0 \mathrm{a}$ & $50.7 \pm 1.5 b$ & $11 . + \pm 1.0 \mathrm{a}$ \\
\hline Trees & $3.6 \pm 0.7 \mathrm{a}$ & $22.5 \pm 1.0 \mathrm{ab}$ & $63.9 \pm 1.3 \mathrm{c}$ & $33.0 \pm 1.5 b$ & $19.8 \pm 1.6 \mathrm{ab}$ \\
\hline Nonvascular & $17.9 \pm 1.5 b$ & $6.3 \pm 0.7 \mathrm{a}$ & $3.6 \pm 0.7 \mathrm{a}$ & $1.5 \pm 0 .+a$ & $0.8 \pm 0 .+a$ \\
\hline
\end{tabular}

a.b.c. Figures lollowed by the same letter in rows are not significantly different $(P \leq 0.05)$ alcoording to Duncan $s$ multiple range test 
Table 4. Defoliation, by deer, of plants found near tracks in the snow: and average snow depth for January and February in 2 years.

\begin{tabular}{|c|c|c|c|c|c|c|}
\hline \multirow[t]{2}{*}{ Species } & \multicolumn{2}{|c|}{1972} & \multirow[b]{2}{*}{$\begin{array}{c}\% \text { of total } \\
\text { stems used }\end{array}$} & \multicolumn{2}{|c|}{1973} & \multirow[b]{2}{*}{$\begin{array}{c}\% \text { of total } \\
\text { stems used }\end{array}$} \\
\hline & $\begin{array}{c}\text { Number plants } \\
\text { available }\end{array}$ & $\begin{array}{c}\text { Plants used } \\
(\%)\end{array}$ & & $\begin{array}{l}\text { Number plants } \\
\text { available }\end{array}$ & $\begin{array}{l}\text { Plants used } \\
(\%)\end{array}$ & \\
\hline \multicolumn{7}{|l|}{ Forbs } \\
\hline Artemisia campestris & & & & 363 & 4 & 1.0 \\
\hline Calochortus macrocarpus & & & & 49 & 65 & 2.1 \\
\hline Chenopodium album & & & & 58 & 93 & 3.5 \\
\hline Cirsium sp. & 1 & 100 & 0.1 & 11 & 91 & 0.6 \\
\hline Medicago sativa & & & & 5 & 60 & 4.2 \\
\hline Penstemon procerus & & & & 2 & 100 & 0.9 \\
\hline Tragopogon dubius & 11 & 36 & 0.4 & 153 & 86 & 8.4 \\
\hline \multicolumn{7}{|l|}{ Shrubs and trees } \\
\hline Artemisia frigida & 375 & 1 & 2.2 & 129 & 50 & 32.3 \\
\hline Artemisia tridentata & 120 & 9 & 25.6 & 1 & 0 & \\
\hline Chrysothamnus nauseosus & 80 & 32 & 60.6 & 145 & 39 & 44.5 \\
\hline Juniperus spp. & 6 & 67 & 7.1 & 4 & 0 & \\
\hline Pinus ponderosa & 3 & 33 & 0.2 & 2 & 0 & \\
\hline Pseudotsugamenziesii & 21 & 29 & 3.6 & 11 & 55 & 2.5 \\
\hline Rosa spp. & 2 & 50 & 0.1 & & & \\
\hline Total & & & 100 & & & 100 \\
\hline
\end{tabular}

Number surveys

Total survey lengths $(\mathrm{m})$

Number stems utilized

Average snowdepth $(\mathrm{cm})$
Douglasfir, which appeared to be supplied primarily from branches that had frozen and broken off. Foliage from these branches was readily eaten and appeared to be very palatable. The branches came mainly from the upper part of old trees where agitation by wind is greatest and dislodgement more likely to occur. Tucker et al. (1976) found palatability to increase from the bottom to the top of old Douglasfir trees. The availability of this material is sporadic, however, and seems dependent on the depth of snow (Willms et al. 1976). In the first winter (Table 4) deep snow discouraged use of pasture sage, which resulted in greater use of the taller shrubs, big sagebrush and rabbitbrush. In the next winter, snow was not a factor and both pasture sage and forbs were used extensively. The role these forbs play in deer nutrition is not known. Their contribution to the macronutrient intake cannot be considered important as they are low in crude protein (i.e. $3 \%$ ) and presumably in digestible energy. They may, however, be sources of some micronutrients.

Although big sagebrush contributed $26 \%$ of the diet, only $7 \%$ of available plants were used (Table 4). It would appear that individual plants were grazed repeatedly while neighbouring plants were unused. Hanks et al. (1971) attributed this phenomenon to genotypic variation which they were able to distin- guish by examining the composition of phenolic compounds. Similar work was done on rabbitbrush (Hanks et al. 1975) and Douglasfir (Radwan 1972).

\section{Deer Spring Diet}

Forage selection be deer in spring appeared to be in response to palatability and availability. The first new grass that became available was Sandbergs blucgrass. It was palatable forage and eagerly sought after by deer. Although leaf emergence in bluebunch wheatgrass and crested wheatgrass was only a few weeks later than Sandbergs bluegrass, its availability was related more to the extension of new tillers above the barrier of standing old growth. Availability of those two species was, therefore, related to the degree of prior fall grazing by cattle. The availability of bluebunch wheatgrass to deer on grazed sites was generally limited before mid-April and abundant after that time.

Sandbergs bluegrass loses its palatability early in the season. Its shallow root system, a characteristic that ensures early spring growth, is responsible for early maturity as the plant responds to soil moisture depletion. The dependence of Sandbergs bluegrass on spring moisture results in high year-to-year variation in productivity and rate of maturity.

Table 5. Average change $\overline{\mathbf{x}} \pm \mathrm{SEm}$ ) in the ground cover of major plant species, in relation to grazing, from June 1971 to June 1974 on the knoll habitat $(n=6)$.

\begin{tabular}{|c|c|c|c|c|}
\hline \multirow[b]{3}{*}{ Species } & \multicolumn{4}{|c|}{ Ground cover $(\%)$} \\
\hline & \multicolumn{2}{|c|}{ Grazed } & \multicolumn{2}{|c|}{ Ungrazed } \\
\hline & East & Middle & West & ( 3 fields combined) \\
\hline Agropyron spicatum & $+1.2 \pm 2.2 \mathrm{a}$ & $-0.4 \pm 1.9 \mathrm{a}$ & $+0.8 \pm 21 . a$ & $+3.0 \pm 1.2 \mathrm{a}$ \\
\hline Artemisia tridentata & $+0.5 \pm 0.6 \mathrm{a}$ & $+1.5 \pm 3.1 \mathrm{a}$ & $-5.7 \pm 1.9 a^{*}$ & $-0.6 \pm 0.7 \mathrm{a}$ \\
\hline Bromustectorum & $+2.3 \pm 0.8 \mathrm{ab}^{*}$ & $+10.2 \pm 4.0 c^{*}$ & $+8.0 \pm 3.7 b c^{*}$ & $+1.5 \pm 0.9 \mathrm{a}^{*}$ \\
\hline Poa sandbergii & $+2.3 \pm 1.2 a^{*}$ & $+3.0 \pm 1.1 \mathrm{a}$ & $+0.3 \pm 0.8 \mathrm{a}$ & $+2.3 \pm 0.6 \mathrm{a}^{*}$ \\
\hline Stipa comata & $-7.0 \pm 2.0 b^{*}$ & $-14.8 \pm 1.1 \mathrm{c}^{*}$ & $-7.2 \pm 1.7 b c^{*}$ & $-2.6 \pm 1.4 \mathrm{a}^{*}$ \\
\hline
\end{tabular}

a.b.c Figures followed by the same letter in rows are not significantly different according to Duncan's multiple range test $(P \leq 0.05)$.

(hange in cover between years is significantly $(P \leq 0.05)$ greater than zero. 


\section{Indirect Deer-Cattle Interaction}

Fall grazing by cattle may affect deer distribution in spring. The year-to-year variation of distribution and use was observed with permanent pellet survey transects and compared to previous cattle grazing (Table 6 ). The 1972 counts followed 7 years of rest from cattle grazing and could be considered an indication of what distribution would be if cattle had not been allowed on the range. Use among the fields was even, indicating there was no selection for one field over the others. After the first grazing year (1973) there was a decline in the total number of pellet groups counted and a shift in use from the west and middle fields into the east field. The decline in use could be attributed to the mild winter of 1972-73, during which the deer remained on the upper ranges until early spring. The shift into the east field was in response to the ineavy cattle grazing the previous fall which reduced the stubble height of bluebunch wheatgrass and crested wheatgrass. This ensured that spring growth was available to deer earlier in that field than in the others. The same response was noticed the following year when heavy spring grazing in the middle field was followed by a shift in deer use to that field. The next year (1974) all fields were grazed moderately and deer use again was divided evenly among fields. In the last year, deer use shifted to the middle field despite heavy fall use in the west field. The effect of heavy grazing was negated by two factors: one was a wet summer that allowed greater than normal vegetative growth so that the stocking level was moderate; the second factor was a fall fire in the middle field, which simulated the effect of heavy grazing. A 4-year summary of results, based on average percent use following four full stocking levels, is: nil grazing, $35 \%$; light grazing, $26 \%$; moderate grazing, $36 \%$; and high grazing, $56 \%$.

Spring grazing levels also demonstrated an effect on deer distribution. Average use following four stocking levels of that season were: nil, $34 \%$; light, $26 \%$; moderate, $33 \%$; and high, $+2 \%$. The factors affecting this response are not clear. It is possible that spring grazing reduces litter buildup, thus reducing the barrier to green forage in the spring.

\section{Literature Cited}

Daubenmire, R. 1959. A canopy-coverage method of vegetational analysis. Northwest Sci. 33:43-64

Goulden, C.H. 1952. Methods of Statistical Analysis. 2nd ed., John Wiley and Sons Inc., New York. 467 p.

Ilalford, S.A., G.B. Rich, and I. Bergis. 1973. A chrysomelid beetle defoliating big sagebrush in south-central British Columbia. Can. J. Plant Sci. 53:383-384.

Hanks, D.L., E.D. McArthur, A.P. Plummer, B.C. Guinta, and A.C. Blauer. 1975. Chromatographic recognition of some palatable and unpalatable subspecies of rubber rabbitbrush in and around Utah. J. Range Manage. 28:144-148.

Hanks, D.I.., J.R. Brunner, D.R. Christensen, and A.P. Plummer. 1971. Paper chromatography for determining palatability differences in various strains of big sagebrush. U.S. Dep. Agr. Forest Serv. Res. Pap. INT-101. 9 p.

Julander, O. 1955. Deer and cattle range relations in Utah. Forest Sci. l(2):130-139

Kraemer, A. 1973. Interspcific behaviour and dispersion of two sympatric deer species. J. Wildl. Manage. 37(3):288-300.

Marquiss, R.S., L.E. Burtel, G.G. Davis. 1974. Improved forage species for resecding in the San Juan Basin. Colorado State Exp. Sta. Tech. Bull. 122. $20 \mathrm{p}$.

McLean, A., and W. Willms. 1977. Cattle diets and distribution on springfall and summer ranges near Kamloops, B.C. Can. J. Anim. Sci. 57:81-92

Mueggler, W.F. 1965. Cattle distribution on steep slopes. J. Range Manage. 18:255-257

Radwan, M.A. 1972. Differences between Douglasfir genotypes in relation to browsing preferences by black-tailed deer. Can. J. Forest Res. 2:250-255.

Skovlin, J.M., R.W. Harris, G.S. Strickler, and G.A. Garrison. 1976. Effects of cattle grazing methods on ponderosa pine-bunchgrass range in the Pacific Northwest. Li.S. Dep. Agr. Forest Serv. Tech. Bull. 1531. 40 p.

Tucker, R., A. McLean, and D.E. Waldern. 1977. Relative preference by mule deer for six shrubs from range near Kamloops, British Columbia. Can. J. Anim. Sci. 57:375-377

Tucker, R., W. Majak, P.D. Parkinson, and A. McLean. 1976. Palatability of Douglasfir foliage to mule deer in relation to chemical and spatial factors.

J. Range Manage. 29:486-489.

\section{Increase Forage Production Plant PERMA-PEL Range \& Pasture Mixes}

Depend on Ramsey Seed - long a leader in range improvement programs - for the finest clover, subclover, and grass seed mixes. Ramsey provides 3 general mixes for varying rainfall and soil conditions ... plus special mixes for special situations. Introduce your range improvement program to Rhizo-Kote ${ }^{\circledR}$ and Nutri-Kote ${ }^{\circledR}$. The seed coatings that provide a controlled germination zone, aids seedling establishment, and offers optimum rhizobia viability for root nodulation of legumes.

\section{Write or phone for seed mix quotes (and for a free range seeding brochure)}

\section{A RAMSEY SEED, INC.}

P.O. Box 352, Manteca, CA 95336 (209) 823-1721
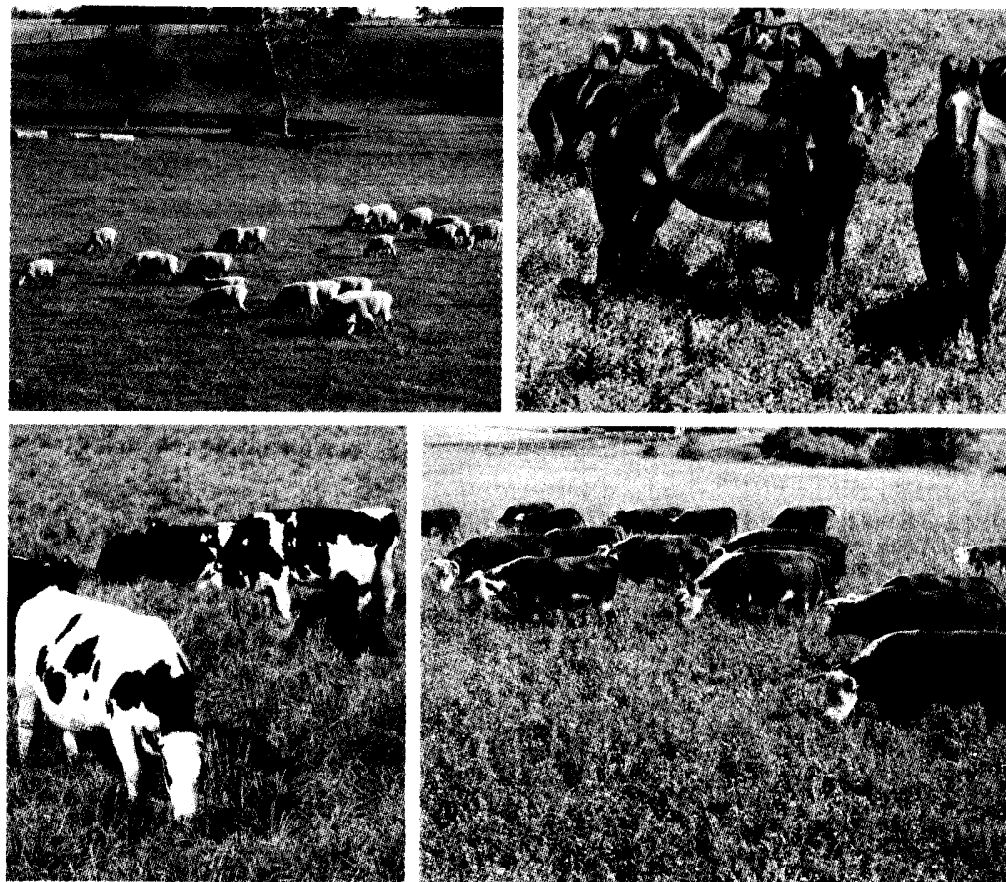